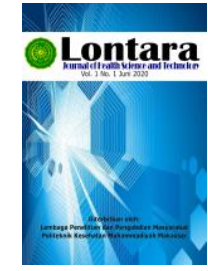

Lontara

Journal of Health Science and Technology

http://jurnal.poltekkesmu.online/lontarariset

Vol 2, No. 1, Juni 2021, pp 49-56

p-ISSN:0000-0000 dan e-ISSN: 2721-6179

DOI:https://doi.org/

\title{
STUDI LITERATUR GAMBARAN HASIL PEMERIKSAAN UREUM PADA PENDERITA TUBERCULOSIS (TB) PARU YANG MENGONSUMSI OBAT ANTI TUBERCULOSIS (OAT)
}

\author{
Tuty Widyanti, Effendy Rasiyanto, Anita, Vindrawati Mooduto
}

Program Studi Teknologi Laboratorium Medis, Politeknik Kesehatan Muhammadiyah Makassar

Email: widyantituty@gmail.com

\section{Artikel info}

\section{Artikel history:}

Received;03-03-2021

Revised:22-05-2021

Accepted;05-06-2021

\section{Keyword:}

Pulmonary tuberculosis, anti tuberculosis drugs, urea.

\section{Kata Kunci:}

TB paru, Obat Anti Tuberculosis (OAT), ureum.
Abstract. Pulmonary Tuberculosis (TB) is an infectious disease of the respiratory tract of the lungs caused by the bacterium Mycobacterium tuberculosis. To treat the disease by using Anti Tuberculosis Drugs (ATD) which is used for 4-6 months. Treatment time that is long enough can affect the kidneys which have an effect until the occurrence of impaired kidney function. One of the important prognostic factors to evaluate the effect of ATD is by observing kidney function using laboratory indicators such as urea examination. This study aims to determine the description of the results of urea levels in pulmonary TB patients who take ATD with the type of literature study research and data collection with library techniques. The samples in this study were journals and scientific papers related to pulmonary $T B$ patients who took ATD with a total of 6 . The method used in this study was a literature study. The results of the study were obtained based on the results of a review of 5 literatures, obtained from 167 samples, obtained normal urea levels as many as 112 (67.1\%) samples and urea levels which increased by 55 (32.9\%) samples so that it can be concluded that patients with tuberculosis (TB) In the lungs, especially those taking ATD, some have normal urea levels and some have an increase.

Abstrak. Tuberkulosis (TB) Paru merupakan penyakit infeksi pada saluran pernapasan bagian paru-paru yang disebabkan oleh bakteri Mycobacterium tuberculosis. Untuk mengobati penyakit tersebut dengan menggunakan Obat Anti Tuberkulosis (OAT) yang pemakaiannya selama 4-6 bulan. Waktu pengobatan yang cukup lama dapat mempengaruhi ginjal yang berefek sampai terjadinya gangguan fungsi ginjal. Salah satu faktor prognosis penting untuk mengevaluasi efek dari OAT adalah dengan melakukan pengamatan pada fungsi ginjal dengan menggunakan indikator pemeriksaan laboratorium seperti pemeriksaan ureum. Penelitian ini bertujuan mengetahui gambaran hasil kadar ureum pada penderita TB paru yang mengonsumsi OAT dengan jenis penelitian studi literatur dan pengumpulan data dengan teknik kepustakaan. Sampel pada penelitian ini adalah jurnal dan karya tulis ilmiah yang berkaitan dengan penderita TB Paru yang mengonsumsi OAT dengan jumlah literatur sebanyak 5. Metode yang digunakan pada penelitian ini yaitu 
studi literatur. Hasil penelitian diperoleh berdasarkan hasil review 5 literatur, didapatkan dari 167 sampel, diperoleh hasil kadar ureum yang normal sebanyak $112(67,1 \%)$ sampel dan kadar ureum yang mengalami peningkatan sebanyak $55(32,9 \%)$ sampel sehingga dapat disimpulkan bahwa penderita Tuberkulosis (TB) Paru khususnya yang mengkonsumsi Obat Anti Tuberculosis (OAT) ada yang kadar ureumnya normal dan ada yang mengalami peningkatan.

Coresponden author:

Email: widyantituty@gmail.com

(c) (1)

artikel dengan akses terbuka dibawah lisensi CC BY -4.0

\section{PENDAHULUAN}

Tuberkulosis TB paru merupakan penyakit saluran pernapasan bagian paru-paru yang disebabkan oleh adanya infeksi bakteri Mycobacterium tuberculosis. Penyakit ini bersifat menular melalui perantara dahak atau droplet penderita TB yang mengandung bakteri di dalam tubuhnya yang akan menularkannya ke orang lain melalui sistem pernafasan. Proses penularan bakteri terjadi ketika penderita TB paru batuk atau bersin yang kemudian akan menyebarkan bakteri ke udara. Setiap kali batuk atau bersin, penderita TB paru dapat mengeluarkan sekitar 3000 percikan dahak ke udara sehingga dapat dengan mudah menginfeksi orang lain yang menghirup udara tersebut. (Naga, 2013)

Penderita TB paru dapat diobati dengan terapi kombinasi obat yang disebut Obat Anti Tuberkulosis (OAT) yang dilakukan selama 6 bulan dengan empat kombinasi obat yaitu isoniazid, rifampisin, pirazinamid dan etambutol. Pengobatan untuk tuberculosis terbagi atas dua tahap yaitu tahap intensif selama 2 bulan dengan menggunakan kombinasi 4 jenis OAT yaitu isoniazid, rifampisin, pirazinamid dan etambutol dan tahap lanjutan selama 4 bulan dengan kombinasi 2 jenis OAT yaitu isoniazid dan rifampisin yang bertujuan untuk menghilangkan sisa-sisa bakteri yang sudah mulai dalam kondisi dorman. (Hoaglend, 2016)

Obat Anti Tuberkulosis (OAT) ketika masuk ke dalam tubuh dapat bersifat toksik jika waktu konsumsi obat tersebut berlangsung lama sehingga akan mempengaruhi organ tubuh antara lain organ hati dan ginjal. Khusus organ ginjal sampai dapat menyebabkan penyakit gagal ginjal dimana organ tersebut tidak lagi dapat berfungsi sebagai alat pembuangan atau eksresi. Dalam proses eksresi, tubuh akan mengeluarkan obat-obatan yang tidak akan bisa lagi diubah atau diproses menjadi produk metabolit. Besarnya molekul zat-zat aktif yang diekskresi akan memperberat fungsi ginjal dan pada akhirnya akan memperburuk fungsinya. Salah satu faktor prognosis penting untuk mengevaluasi efek dari OAT adalah dengan melakukan pengamatan pada fungsi ginjal dengan menggunakan indikator pemeriksaan laboratorium seperti pemeriksaan ureum. (Verdiansah, 2016) 
Studi Literatur Gambaran Hasil Pemeriksaan Ureum Pada Penderita Tuberculosis (Tb) Paru yang Mengonsumsi Obat Anti Tuberculosis (Oat)

(Tuty Widyanti, Effendy Rasiyanto 2, Anita 3, Vindrawati Mooduto 4)

Ureum merupakan produk akhir katabolisme protein dan asam amino yang dihasilkan oleh hati yang kemudian disalurkan melalui cairan intraseluler dan ekstraseluler ke dalam darah yang akan disaring oleh glomerulus pada ginjal. Pemeriksaan ureum dapat diukur dari bahan pemeriksaan plasma ataupun serum (Verdiansah. 2016). Menurut penelitian yang dilakukan oleh Nanda. N.T. (2015), mengenai Analisa Kadar Ureum Dalam Serum Penderita TB Paru Yang Mengkonsumsi Obat Anti Tuberkulosis Lebih Dari 4 Bulan, diperoleh hasil kadar ureum pada penderita TB paru dari jumlah 20 sampel, 17 sampel (85\%) kadar ureum yang normal, dan 3 sampel (15\%) kadar ureum meningkat.

Berdasarkan uraian latar belakang di atas, peneliti tertarik melakukan studi literatur untuk mengkaji tentang Gambaran Hasil Pemeriksaan Ureum Pada Penderita Tuberculosis (TB) Paru Yang Mengonsumsi Obat Anti Tuberkulosis (OAT).

\section{BAHAN DAN METODE}

Jenis penelitian ini adalah penelitian studi literatur dengan mencari referensi teori tentang Gambaran Hasil Ureum pada Penderita Tuberculosis (TB) paru yang mengonsumsi Obat Anti Tuberculosis (OAT). Populasi penelitian ini adalah semua Jurnal/KTI yang berkaitan dengan penderita TB Paru yang mengkonsumsi OAT dengan sampel berjumlah 5 Jurnal dan KTI yang berkaitan dengan seluruh penderita TB Paru yang mengkonsumsi OAT. Adapun teknik pengumpulan data menggunakan Jurnal, KTI dan Skripsi dari berbagai sumber seperti google cendekia, google scholar dan situs penyediaan jurnal online. Kata kunci yang digunakan dalam pencarian literatur antara lain: ureum penderita TB Paru, Obat Anti Tuberculosis (OAT), dan Tuberculosis Paru.

Pada penelitian ini menggunakan 13 literatur penelitian yang diambil dari tahun 2015-2019. Kemudian dipilih 5 penelitian yang berkaitan dengan judul gambaran hasil pemeriksaan ureum pada penderita TB paru yang mengonsumsi OAT. Selanjunya penelitian yang telah terpilih akan dibandingkan sesuai dengan teori. Kemudian data yang didapatkan diolah dalam bentuk tabel dan dinarasikan secara deskriptif.

\section{HASIL PENELITIAN}

Berdasarkan hasil studi literatur yang dilakukan pada beberapa jurnal dan KTI dari tahun 2015-2019 yang berkaitan dengan Gambaran Hasil Pemeriksaan Ureum Pada Penderita Tuberculosis (TB) Paru Yang Mengonsumsi Obat Anti Tuberculosis (OAT), didapatkan hasil yaitu dari 5 penelitian, semuanya membahas tentang ureum pada penderita TB paru yang mengonsumsi OAT.

Adapun 5 penelitian yang direview terdiri dari : 1). Nanda. N. T (2015) dengan judul penelitian yaitu : Analisa Kadar Ureum Dalam Serum Penderita TB Paru Yang Mengkonsumsi Obat Anti Tuberkulosis Lebih Dari 4 Bulan Di UPT Kesehatan Paru Masyarakat Medan Tahun 2015; 2). Harison M. Fery (2019) dengan judul : Gambaran Kadar Ureum Dan Kreatinin Pada Penderita Tuberkulosis Paru Yang Mendapat Terapi Obat Anti Tuberkulosis (OAT) Di RS. Khusus Paru 
Provinsi Sumatera Selatan Tahun 2019; 3). Djasang S, Meli Saturiski (2019) yang berjudul : Studi Hasil Pemeriksaan Ureum Dan Asam Urat Pada Penderita TB Paru Yang Mengonsumsi OAT Fase Intensif; 4). Mustifa, Sugireng (2019) dengan judul penelitian : Fungsi Ginjal Penderita TB Paru Setelah Penggunaan OAT Kategori 1 Di Puskesmas Katobu Kab Muna; dan 5). Lethet c. Ujneng A., Zul A dengan judul penelitian yaitu Analisis kadar Ureum, kreatinin serum dan albumin urin pada penderita tuberculosis yang mendapat terapi obat anti tuberculosis 6 bulan di RSUD Labuang Baji Makassar.

Pada studi literatur ini ditemukan adanya persamaan dan perbedaan pada sampel yang digunakan oleh para peneliti. Pada penelitian yang dilakukan oleh Nanda. N. T (2015) menggunakan sampel serum sebanyak 20 sampel; Harison M. Fery (2019) menggunakan sampel serum sebanyak 43 sampel; Djasang S, Meli Saturiski (2019) menggunakan sampel serum sebanyak 30 sampel; Mustifa, Sugireng (2019) menggunakan sampel serum sebanyak 36; dan Lethet c. Ujneng A., Zul A dengan jumlah sampel 38 berupa serum.

Metode penelitian yang digunakan pada masing-masing 5 penelitian yaitu deskriptif crosssectional yang dilakukan oleh Nanda. N. T (2015). Untuk metode deskriptif observasional dipilih sebagai metode penelitian oleh Harison M. Fery (2019); Dan metode deskripsi dipilih oleh Djasang S, Meli Saturiski (2019); Mustifa, Sugireng (2019); dan Lethet c. Ujneng A., Zul A.

Dari 5 penelitian yang direview, diperoleh hasil untuk masing-masing penelitian yaitu Nanda. N. T (2015) dengan hasil penelitian menunjukkan dari 20 sampel, terdapat 17 sampel (85\%) kadar ureumnya normal dan 3 sampel (15\%) yang kadar ureumnya meningkat. Penelitian yang dilakukan oleh Harison M. Fery (2019) diperoleh hasil 43 pasien tuberkulosis paru yang mendapat terapi OAT, 38 orang $(88,4 \%)$ kadar ureum normal dan 5 orang $(11,6 \%)$ kadar ureum tinggi. Penelitian yang dilakukan oleh Mustifa, Sugireng (2019) dengan hasil penelitian dari 36 reponden, yang memeiliki kadar ureum normal adalah sebanyak 30 dan kadar ureum yang abnormal sebanyak 6 responden. Penelitian yang telah dilakukan oleh Djasang S, Meli Saturiski (2019) yaitu dari 30 sampel penderita tuberculosis paru diperoleh hasil pemeriksaan ureum yang meningkat $5(16,67 \%)$ sampel dan 25 (83,33\%) sampel menunjukkan kadar ureum normal, dan Lethet c. Ujneng A., Zul A memperoleh hasil penelitian yaitu adanya kenaikan ureum $94,7 \%$ (36 org), normal 2 org $(5,3 \%)$.

\section{PEMBAHASAN}

Ureum merupakan hasil akhir metabolisme protein. Ureum dibentuk dalam hepar, difiltrasi di glomerulus dan direabsorbsi di tubulus dalam jumlah yang bervariasi. Reabsorbsi ureum ini menjadi lebih besar dengan meningginya kadar ureum dalam urine dan sebaliknya reabsorbsi berkurang bila urine makin cair. Oleh karena itu penentuan kadar ureum dalam serum berperan sebagai indikator yang peka terhadap kelainan fungsi ginjal (Depkes RI, 2003).

Pada penelitian ini dari 167 sampel, sebanyak 55 sampel yang mengalami peningkatan kadar ureum. Hal ini disebabkan karena terjadinya reabsorpsi ureum yang tinggi di bagian tubulus ginjal 
Studi Literatur Gambaran Hasil Pemeriksaan Ureum Pada Penderita Tuberculosis (Tb) Paru yang Mengonsumsi Obat Anti Tuberculosis (Oat)

(Tuty Widyanti, Effendy Rasiyanto 2, Anita 3, Vindrawati Mooduto 4)

pada penderita TB Paru sedangkan terdapat 112 sampel yang mempunyai kadar ureum yang normal yang berarti pada proses reabssopsi ureum pada ginjal penderita TB paru yang dilakukan pada bagian tubulus, terjadi dalam keadaan normal.

Berdasarkan data yang diperoleh pada jurnal dan KTI dari 5 penelitian tersebut dalam menentukan kadar ureum, semua penelitian menggunakan metode spektrofotometer. Prinsip kerja spektrofotometer adalah adanya penyerapan cahaya pada panjang gelombang tertentu oleh bahan yang diperiksa. Pada prinsipnya, setiap zat memiliki absorbansi pada panjang gelombang tertentu. Untuk mengukur kadar zat yang diperiksa, maka yang diukur adalah panjang gelombang dengan absorbansi tertinggi. Semakin banyak cahaya yang diabsorbsi oleh zat maka kadar zat juga semakin besar. Dalam proses kerja alat tersebut, dibutuhkan ketepatan pengukuran dimana kadar yang akan diukur dibandingkan dengan kadar yang diketahui (standar) lalu setelah itu dimasukan blangko (Kemenkes RI. 2010). Kelebihan penggunaan spektrofotometer dalam menentukan kadar ureum adalah untuk menetapkan kuantitas zat yang sangat kecil dengan memberikannya cahaya yang sederhana. Selain itu, angka yang terbaca langsung dicatat oleh detektor dan langsung tercetak dalam bentuk angka digital atau grafik yang sudah diregresikan sehingga hasil yang diperoleh cukup akurat. (Sripatundita, 2013)

Pada 5 hasil penelitian terdapat sebanyak 55 sampel dari 167 sampel diperoleh adanya peningkatan kadar ureum pada pendertita TB paru yang mengkonsumsi OAT. Menurut Harison M. Fery (2019) bahwa "peningkatan kadar ureum ini disebabkan karena adanya efek yang memang ditimbulkan pada saat mengkonsumsi OAT tersebut seperti jenis OAT rifampisin dan streptomisin. Ketika mengkonsumsi rifampisin akan terbentuk kompleks antibodi di pembuluh darah ginjal yang dapat menyebabkan endoteliosis glomerular. Adanya penumpukan kompleks antibodi di pembuluh darah akan berdampak pada penyempitan pembuluh darah dan iskemia tubulus sehingga menyebabkan nekrosis tubulus. Efek dari hal tersebut terjadi penurunan fungsi ginjal. Untuk streptomisin, mekanisme nefrotoksik terjadi ketika aminoglikosida masuk ke dalam korteks ginjal dan tubulus proksimal, melalui proses endositosis dan sequestration, dimana aminoglikosida akan berikatan dengan lisosom dan membentuk myeloid bodies/secondary lysosome. Kemudian membran lisosom pecah dan melepaskan asam hidrolase yang mengakibatkan kematian sel sehingga menyebabkan penurunan fungsi ginjal”. (Singh, 2003)

Akibat dari mengkonsumsi OAT, menurut Djasang S, Meli Saturiski (2019) bahwa "OAT yang dikonsumsi dapat menyebabkan berkurangnya kemampuan fungsi ekskresi pada ginjal sehingga senyawa-senyawa obat yang tidak termetabolisme akan dikeluarkan melalui ginjal. Pada organ ini terjadi proses ekskresi dimana ketika obat masuk ke dalam tubuh akan melawati tiga proses yaitu filtrasi glomerulus, sekresi aktif di tubulus proksimal, dan reabsorbsi pasif di sepanjang tubulus. Ketika difiltrasi pada glomelurus terjadi disfungsi pada ginjal dalam menghasilkan ultrafiltrat yaitu plasma minus protein dimana semua obat bebas akan keluar dalam ultrafiltrasi sedangkan yang terikat protein tetap tinggal dalam darah". 
Adanya peningkatan kadar ureum pada pasien yang menderita TB paru yang mengkonsumsi Obat Anti Tuberculosis (OAT) menurut Lethet c. Ujneng A., Zul A bahwa "mengkonsumsi OAT terutama dalam jangka waktu yang lama dan dalam jumlah yanga banyak akan berpengaruh terhadap fungsi organ ginjal yang akan mengakibatkan kadar ureum dan atau kreatinin akan meningkat. Hal ini disebabkan karena fungsi ginjal adalah sebagai alat eksresi tubuh, dimana senyawa-senyawa obat yang tidak termetabolisme akan dikeluarkan oleh ginjal".

Penggunaan obat yang tidak tepat waktu dan tidak sesuai dengan aturan dokter juga akan berpengaruh terhadap fungsi organ ginjal yang bisa mengakibatkan kerusakan fungsi ginjal. Kadar ureum akan meningkat jika ginjal tidak mampu berkerja dengan baik akibat kerusakan fungsi ginjal. Apalagi jika penderita TB paru sebelumnya telah memiliki riwayat gagal ginjal. Peningkatan kadar ureum juga disebabkan karena mengkonsumsi makanan yang tinggi protein, dimana ureum merupakan hasil metabolisme protein.

Menurut Djasang S, Meli Saturiski (2019) bahwa “orang yang terlalu banyak mengonsumsi makanan yang mengandung tinggi protein, asupan makanan yang tinggi protein akan menyebabkan tingginya kadar ureum dan kreatinin. Kondisi susah buang air kecil pada penderita, sehingga ureum yang seharusnya dikeluarkan melalui urin menjadi menumpuk dalam darah. Tingginya kadar ureum dalam darah yang tidak bisa dikeluarkan karena fungsi ginjal yang menurun dapat menjadi toksik di dalam tubuh karena ureum sendiri merupakan suatu zat sisa metabolisme protein".

Menurut Mustifa, Sugireng (2019) bahwa "kenaikan kadar ureum juga dapat terjadi karena kurang asupan air putih dan banyak mengkonsumsi makanan yang manis. Terkait dengan gaya hidup yang kurang mengkonsumsi air putih, memenuhi kebutuhan akan asupan air putih sangatlah penting, dimana air putih dapat membuang racun dalam tubuh. Kurang minum air putih dapat memicu penumpukan racun limbah tubuh dalam darah yang dapat mengganggu fungsi ginjal dan bahkan dapat menyebabkan kerusakan parah pada ginjal. Air putih dapat membantu membuang racun dan kotoran dari dalam tubuh sehingga tubuh terhidrasi dengan baik, hal ini membantu ginjal dalam menjalankan fungsinya".

Seorang yang mempunyai penyakit diabetes melitus (DM) juga memiliki resiko kadar ureum dalam darahnya meningkat. Hal ini disebabkan seorang dengan kadar gula yang tinggi dalam darahnya bisa membuat bakteri Mycobacterium tuberculosis sebagai penyebab TB paru akan berkembang dalam tubuh, termasuk jika sudah terinfeksi sebelumnya yang akan membuat bakteri TB laten menjadi aktif kembali. Akibatnya seorang tersebut akan mengkonsumsi obat dengan kombinasi obat DM dengan OAT sehingga dapat menambah kerja ginjal yang pada akhirnya akan berefek dengan meningkatnya kadar ureum dalam darah. (Cahyaningsih. 2014), (Sugireng., 2019)

Untuk pasien penderita TB Paru yang kadar ureumnya normal menurut Nanda. N. T (2015) bahwa "kemungkinan penderita TB Paru mengkonsumsi OAT secara teratur, mengikuti petunjuk Dokter dan menjaga pola makan sehingga tidak terjadi perubahan terhadap kadar ureum dalam tubuhnya". 
Studi Literatur Gambaran Hasil Pemeriksaan Ureum Pada Penderita Tuberculosis (Tb) Paru yang Mengonsumsi Obat Anti Tuberculosis (Oat)

(Tuty Widyanti, Effendy Rasiyanto 2 , Anita 3, Vindrawati Mooduto 4)

Selain itu kadar ureum normal yang didapatkan pada 112 sampel dari 167 sampel menunjukkan bahwa tidak semua OAT dapat menyebabkan gangguan fungsi ginjal apabila dikonsumsi dengan tepat waktu dan sesuai petunjuk dokter. Konsumsi OAT pada 2 bulan pertama akan berefek terhadap kerusakan pada fungsi ginjal terutama pada bagian tubulus ginjal. Namun kerusakan ini bersifat reversible yang akan kembali normal pada 3-4 bulan pengobatan. Pada 4 bulan tahap lanjutan, dosis obat akan diturunkan sehingga resiko nefrotoksik (obat yang bersifat meracuni atau mengganggu fungsi ginjal) dapat dikurangi maka akan didapatkan sebagian besar kadar ureum masih normal. (Nursidika. P., dkk. 2017)

\section{KESIMPULAN}

Berdasarkan hasil studi literatur yang dilakukan sebanyak 5 penelitian, dapat disimpulkan bahwa kadar ureum pada penderita TB paru yang mengonsumsi OAT dapat mengalami peningkatan yang disebabkan beberapa faktor antara lain karena pasien TB mengkonsumsi OAT dalam jangka waktu yang lama, disertai dengan menggunaan obat yang tidak teratur dan tidak mengikuti petunjuk dokter, sehingga berpengaruh terhadap fungsi organ ginjal yang bisa mengakibatkan kerusakan fungsi ginjal, akibatnya ureum yang direabsorpsi di bagian tubulus ginjal menjadi lebih banyak maka didapatkan kadar ureum meningkat. Namun kebanyakan kadar ureum pada penderita TB paru yang mengonsumsi OAT dalam keadaan normal.

\section{SARAN}

Untuk peneliti selanjutnya melakukan penelitian tentang perbandingan kadar ureum pada penderita TB paru yang mengkonsumsi OAT secara teratur dan yang tidak teratur. Untuk penderita TB paru yang mengonsumsi OAT sangat diharapkan untuk tetap rutin melakukan pemeriksaan ke dokter dan mengontrol kadar ureumnya agar dapat diketahui kondisi organ tubuhnya terkhusus organ ginjal dari hasil pemeriksaan ureum tersebut.

\section{DAFTAR PUSTAKA}

Cahyaningsih. 2014. Panduan Praktis Perawatan Gagal Ginjal. Mitra Cendekia Press. Yogyakarta.

Djasang S, Meli Saturiski. 2019. Studi hasil pemeriksaan ureum dan asam urat pada penderita TB paru yang mengonsumsi OAT Fase intensif. Jurnal Media Analis Kesehatan/ Vol. 10, No.1/ Juni 2019.

Harison M. Fery., 2019. Gambaran Kadar Ureum Dan Kreatinin Pada Penderita Tuberkulosis Paru yang Mendapat Terapi Obat Anti Tuberkulosis (OAT) Di RS. Khusus Paru Provinsi Sumatera Selatan Tahun 2019. KTI diterbitkan. Palembang: Poltekkes Kemenkes Palembang.

Hoaglend, D.T., Liu, J., Lee, R.B. \& Lee., R.E., 2016, Agen Baru untuk Pengobatan Mycobacterium Tuberculosis yang Tahan Obat, Ulasan Pengiriman Obat Lanjut, 102, 55-72 
Kemenkes RI. 2010. Pedoman Pemeriksaan Kimia Klinik. Menteri Kesehatan RI. Jakarta.

Mustifa, Sugireng., 2019. Fungsi Ginjal Penderita TB Paru setelah penggunaan OAT kategori 1 di Puskesmas Katobu kab muna. Jurnal Media Lab Mandala Waluya Kendari/ Vol.3 No.1/ Juli 2019

Naga, Sholeh S. 2013. Buku Psanduan Lengkap Ilmu Penyakit Dalam. Diva Press. Jogjakarta.

Nanda. N. T., 2015. Analisa Kadar Ureum Dalam Serum Penderita TB Paru Yang Mengkonsumsi Obat Anti Tuberkulosis Lebih Dari 4 Bulan Di UPT Kesehatan Paru Masyarakat Medan Tahun 2015. KTI Diterbitkan. Medan : Universitas Sari Mutiara Indonesia.

Nursidika. P., dkk. 2017. Gambaran abnormal organ hati dan ginjal Pasien Tuberkulosis Yang Mendapatkan Pengobatan. Jurnal Kesehatan Kartika 12 (1) : 1-11.

Singh, NP., A. Ganguli., A. Prakash. 2003. Drug Induced Kidney Disease. J Assoc Physicians India.

Verdiansah. 2016. Pemeriksaan fungsi ginjal. Jurnal praktisi.43 cdk-237

Yahya, Sripatundita, 2013. Jurnal Spektrofotometer-Uv-Vis. 